\title{
BETWEEN ANTHROPOCENTRISM AND ANTHROPOMORPHISM: A CORPUS-BASED ANALYSIS OF ANIMAL COMPARISONS IN SHAKESPEARE'S PLAYS
}

\author{
SORINA POSTOLEA \\ LORELEI CARAMAN \\ Alexandru Ioan Cuza University of Iaşi
}

\begin{abstract}
The assertion of the centrality and supremacy of man, or rather, of the idea(l) of humanity, during the Renaissance period, inevitably entailed the repudiation of the animal and the beginning of the great human-animal divide. What was seen, at the time, as the re-birth of man, was also the birth of a rampant anthropocentrism which, until the recent so-called "animal turn" in critical and literary studies went unquestioned. Taking this into account, one would expect to find an almost exclusive focus on the human or what is/was perceived as being human in most works from that period. Yet, surprisingly, throughout Shakespeare's plays, one encounters a plethora of figures of animality leaping, running, crawling, flying, swimming, or advancing, as Derrida would say, "à pas de loup". From dogs, bears, lions, apes and foxes to birds, fish, worms and reptiles, Shakespeare the humanist paradoxically unfolds a veritable bestiary of nonhuman presences. Using corpus-based analysis that focuses on animal similes built with the preposition "like" and a critical angle largely informed by posthumanist theory, we take a closer look at the forms, roles and functions of both nonhuman and human animality in Shakespeare, as well as the intricate relationship between anthropocentrism and anthropomorphism.
\end{abstract}

Keywords: Shakespeare, Shakespeare's animals, nonhuman, human-animal studies, corpus linguistics, posthumanism, animal similes, comparisons

Shakespeare, Harold Bloom tells us, invented us as humans. For many years, critics and theoreticians have focused on all the forms and complexities of this invention. Yet our paper turns not towards the overly-analyzed central human in Shakespeare, but to the less explored, marginalized non-human. Paradoxically enough, his plays abound in figures of animality. But what kind of animals appear in his plays? Which are the most invoked? Are they depicted negatively 
or positively? What does his representation of animality tell us about human animality and humanist perspectives on animality? What can be said about Shakespeare the (probable and possible) humanist from a posthumanist perspective? These are some of the questions which our inquiry tries to raise and address. The methodology we have employed combines linguistics, more specifically, corpus analysis, with a theoretical angle largely informed by posthumanism. Essentially, we have endeavoured to explore the relation between anthropocentrism and anthropomorphism, as well as the possible interplay between the two phenomena focusing on a single figure of speech that might constitute an illustrative estimation of both, i.e. animal similes.

\section{Searching for Human-Animal Similes}

As mentioned before, a measure of the relationship between humanity and animality in Shakespeare's plays would undoubtedly be given by the very rich web of animal presences and their roles found therein. However, because an exhaustive inventory of all the animal imagery in the Bard's works would require years of research, for this article we chose to focus on only a very small part of it, i.e. animal similes, and, specifically, on direct comparisons built with the preposition like. Our methodology was informed by the approaches and techniques specific to corpus linguistics (McEnery, Hardie 2012; Meyer 2004; O'Keeffe, McCarthy 2010; Stubbs 2002) and involved several steps. We used the collection of Shakespeare's canonical plays available on the Wordsmith website $^{1}$. This corpus is based on the 1916 Oxford University Press edition of the Bard's works and comprises 17 comedies, 10 tragedies, and 10 historical plays.

The texts were explored using AntConc (Anthony 2014)-a monolingual concordancer-and UAM CorpusTool, an annotation program. The first step was to retrieve all the occurrences of the type like in the corpus. The 1715 concordance lines produced by this operation were then analysed so as to extract only the similes in which one of the compared terms (usually, the secundum comparandum) referred to an animal. We were thus able to identify 185 "like + animal" direct comparisons. These were then manually annotated by type of animal (e.g. mammal/bird/reptile; domestic/wild, etc.) and by type of comparison (e.g. animal(s) compared with a human/non-human element; positive/negative/neutral connotation, etc.). The overall goal was to see how many of these similes involved a human and an animal component and what the nature of the relationship established between them was.

\footnotetext{
${ }^{1}$ http://lexically.net/wordsmith/support/shakespeare.html [accessed on July 12, 2016]
} 


\section{'Tis Like a Beast, Methinks: Animal Figures in Shakespeare's Like- Comparisons}

Our methodology revealed, once more, the extraordinary richness and astounding resourcefulness of Shakespeare's vocabulary and writing style as well as the exceptional wealth of animal figures present in his plays. The first criterion used to classify the 185 direct comparisons identified according to the steps described above was the type of animal mentioned. We used six categories: 1) mammals; 2) birds; 3) fish and water animals; 4) insects and worms; 5) reptiles and amphibians; and 6) a group of "other" animal types where we included fantastic, mythological, or invented beasts (e.g. Perseus' horse, Juno's swans, dragon, harpy, basilisk, etc.) as well as general words referring to animality (e.g. beast(s) or buck).

\begin{tabular}{|l|c|c|}
\cline { 2 - 3 } \multicolumn{1}{l|}{ TYPE OF ANIMAL } & OCCURRENCES & PERCENTAGE \\
\hline Mammals & 104 & $\sim 56 \%$ \\
\hline Birds & 40 & $\sim 22 \%$ \\
\hline Other & 13 & $\sim 8 \%$ \\
\hline Insects \& worms & 12 & $\sim 6 \%$ \\
\hline Fish \& water animals & 12 & $\sim 6 \%$ \\
\hline Reptiles \& amphibians & 4 & $\sim 2 \%$ \\
\hline
\end{tabular}

Table 1: Animal comparisons by type of animal

As shown in Table 1, more than half of the 185 similes of interest here refer to various kinds of mammal. They include both domestic and wild species, although the difference is sometimes hard to pinpoint, as in the following lines from Richard III:

Because that I am little, like an ape,

He thinks that you should bear me on your shoulders. (3.1.130-131)

Taking into account the criterion of domesticity, the mammals mentioned by Shakespeare in his direct like-comparisons may be further divided as follows, even if, of course, these categories are not clear-cut:

\begin{tabular}{|l|c|l|c|l|c|}
\hline \multicolumn{2}{|c|}{ DOMESTIC } & \multicolumn{4}{c|}{ WILD } \\
MAMMALS (56/104) & \multicolumn{4}{c|}{ MAMMALS (48/104) } \\
\hline TYPE & N & TYPE & N & TYPE & N \\
\hline Dog & 24 & Ape & 10 & Mouse & 2 \\
\hline Horse & 10 & Lion & 7 & Porpentine & 2 \\
\hline Bull & 9 & Deer & 4 & Leopard & 1 \\
\hline
\end{tabular}




\begin{tabular}{|l|l|l|l|l|l|}
\hline Ass/Mule & 5 & Rat & 4 & Hyen & 1 \\
\hline Sheep & 3 & Wolf & 3 & Hedge-hog & 1 \\
\hline Swine & 2 & Boar & 3 & Hare & 1 \\
\hline Cat & 2 & Bear & 3 & Camel & 1 \\
\hline Rabbit & 1 & Shrew & 2 & Weasel & 1 \\
\hline
\end{tabular}

Table 2: Domestic versus wild mammal types

The animal types in Table 2 are generic, meaning that each category includes both singular and plural forms, as well as, in some cases, various words that refer to the same species. For instance, the 4 occurrences of deer include the following forms: deer (2), doe (1), and stag (1). All in all, like-comparisons referring to mammals mention no less than 45 different animals. This is yet another measure of Shakespeare's incredible versatility and creativity, since he seldom used the same animal twice in his direct analogies.

The same bewildering variety is visible in the case of the 40 bird similes identified in the corpus. If with mammals domestic types are slightly more frequent, when it comes to avian comparisons Shakespeare seems to have clearly favoured the wild (30 occurrences). Household birds count only 8 mentions and, out of these, 5 refer to the male chicken: as cock in "...and I / must go up and down like a cock, that nobody can / match" (Cymbeline, 2.1.20-22) and "You were / wont, when you laughed, to crow like a cock" (The Two Gentlemen of Verona, 2.1.24-25); as chanticleer in "My lungs began to crow like chanticleer" (As You Like It, 2.7.30); as craven in "No cock of mine, you crow too like a craven" (The Taming of the Shrew, 2.1.225); and as turkey-cock in "Why, here he comes, swelling like a turkey-cock" (Henry V, 5.1.14). The list of domestic birds mentioned in Shakespeare's like-comparisons is completed by the goose (2) and the $d u c k$ (1). On the flip side, no less than 19 different birds make up the bestiary of wild avian creatures used by the Bard in his similes:

\begin{tabular}{|c|c|c|c|c|c|c|c|c|c|}
\hline TYPE & $\mathbf{N}$ & TYPE & $\mathbf{N}$ & TYPE & $\mathbf{N}$ & TYPE & $\mathbf{N}$ & TYPE & $\mathbf{N}$ \\
\hline eagle & 4 & peacock & 2 & crow & 1 & raven & 1 & buzzard & 1 \\
\hline $\begin{array}{l}\text { wild } \\
\text { goose }\end{array}$ & 3 & lark & 2 & lapwing & 1 & ostrich & 1 & haggard & 1 \\
\hline parrot & 3 & pelican & 2 & martlet & 1 & mallard & 1 & estrige & 1 \\
\hline owl & 2 & vulture & 1 & $\begin{array}{l}\text { robin- } \\
\text { redbreast }\end{array}$ & 1 & swallows & 1 & & \\
\hline
\end{tabular}

Table 3: Wild birds in like-comparisons 
This category also includes two like-comparisons containing the general word bird, in "We two alone will sing like birds i' the cage" (King Lear, 5.3.9) and "Where, like a sweet melodious bird, it sung" (Titus Andronicus, 3.1.85).

The group of "fish and water animals" counts 12 similes.

\begin{tabular}{|c|c|c|c|}
\hline \multicolumn{4}{|c|}{ FISH AND WATER ANIMALS (12) } \\
\hline TYPE & $\mathbf{N}$ & TYPE & N \\
\hline crab & 2 & urchin & 1 \\
\hline school & 2 & fish & 1 \\
\hline whale & 2 & tench & 1 \\
\hline herring & 1 & loach & 1 \\
\hline ling & 1 & \multicolumn{3}{|c}{}
\end{tabular}

Table 4: Fish and water animal types

Stricto sensu, there are actually 3 comparisons encompassing the word whale. However, two mentions occur in a scene from Hamlet where the Prince and Polonius discuss the shape of a cloud:

Hamlet: Do you see yonder cloud that's almost in shape of a camel?

Polonius: By th' mass, and 'tis like a camel indeed.

Hamlet: Methinks it is like a weasel.

Polonius: It is backed like a weasel.

Hamlet: Or like a whale.

Polonius: Very like a whale. (3.2.383-389)

Because the two occurrences in this excerpt have the same referent, we counted this simile only once (the same goes in the case of weasel).

This is also the only category of like-comparisons that includes a collective noun, school (scull). Even if it is not a word designating an animal per se, we decided to include it in our analysis because it nevertheless signals a nonhuman presence, albeit a group one. As a matter of fact, in both of its occurrences, the context makes it clear that Shakespeare talks about fish: "And there they fly or die, like scaled schools / Before the belching whale" (Troilus and Cressida, 5.5.22-23) and "...or like a school broke up / Each hurries toward his home and sporting-place" (Henry IV Part 2, 4.2.104-105).

Another word worth mentioning in this context is ling, which does not refer to a living animal but to one which has been prepared for human consumption, i.e. dry and salted cod. In Shakespeare's time, the term also had a use that illustrates our case in point, referring to a person that shared a similar appearance: "Our / old lings and our Isbels o'th' country are nothing like / your old ling and your Isbels o'th' court" (All's Well That Ends Well, 3.2.12-14). 
The category of "insects and worms" includes 9 animal species that, together, count 12 occurrences.

\begin{tabular}{|c|c|c|c|}
\hline \multicolumn{4}{|c|}{ INSECTS AND WORMS (12) } \\
\hline TYPE & $\mathbf{N}$ & TYPE & $\mathbf{N}$ \\
\hline bee & 4 & horse-leeches & 1 \\
\hline glow-worm & 1 & fly & 1 \\
\hline gnat & 1 & summer-flies & 1 \\
\hline butterfly & 1 & snail & 1 \\
\hline worm & 1 & \multicolumn{2}{l}{} \\
\cline { 1 - 2 }
\end{tabular}

Table 5: Insect and worm types

The type bee encompasses three comparisons that use the word itself, two of which are to be found within a few lines from Henry IV Part 2, in an extended analogy/metaphor:

When, like the bee tolling from every flower,

Our thighs packed with wax, our mouths with honey,

We bring it to the hive; and like the bees

Are murdered for our pains. (4.5.76-79)

Interestingly enough, the third like-simile referencing the bee is also used in a historical play, i.e. Henry VI Part 2: "The commons, like an angry hive of bees / That want their leader, scatter up and down" (3.2.125-126). The fourth member of the bee family of similes is drone, mentioned once in the comedy Pericles, the Prince of Tyre.

The final and the least substantial category of animals used to form likecomparisons in Shakespeare's plays is represented by "reptiles and amphibians". There are only 4 mentions of these creatures in the corpus, all of them in similes that bear negative connotations. The snake is referenced twice as serpent in "Hang off, thou cat, thou burr! Vile thing, let loose / Or I will shake thee from me like a serpent" (A Midsummer Night's Dream, 3.2.260-261) and in "And both like serpents are, who, though they feed / On sweetest flowers, yet they poison breed" (Pericles, 1.1.133-134), and as adder in "What! Art thou like the adder waxen deaf?" (Henry VI Part 2, 3.2.76). The last member in this category is the toad, referenced in "Sweet are the uses of adversity, / Which, like the toad, ugly and venomous, / Wears yet a precious jewel in his head" (As You Like It, 2.1.12-14).

All in all, the 185 like-comparisons on which this study focuses mention a total number of 102 different animals, i.e. a ratio of 0.55 which shows that only a very small group of animals are used in these similes more than once. However, our analysis also revealed that the Bard did seem to favour some types 
of animal figures in his direct comparisons: mammals and (far less frequently) birds prevail in these figures of speech. Moreover, within these categories, some animals seem to emerge in the playwright's imaginary universe more often than others. In a top of the five most referenced animals in like-comparisons in Shakespeare's plays, dogs would win the first place by a landslide. They are mentioned 24 times (more than double the number of occurrences of the runnerups) as:

- $\operatorname{dog}(s)-11$ occurrences, e.g. "Knowing naught - like dogs - but following" (King Lear, 2.2.78)

- hound $(s)-5$ occurrences, e.g. "I do follow here in the chase, not like a hound / that hunts, but one that fills up the cry" (Othello, 2.3.354)

- greyhound(s) - 4 occurrences, e.g. "O sir, Lucentio slipped me like his greyhound" (The Taming of the Shrew, 5.2.52)

- $\operatorname{cur}(s)-3$ occurrences, e.g. "I spurn thee like a cur out of my way" (Julius Caesar, 3.1.46)

- spaniel - 1 occurrence, in "...let me be gelded like a spaniel" (Pericles, 4.6.122)

Dogs are, therefore, a paramount animal presence in Shakespeare's imaginary, even at the level of these similes. As a matter of fact, the type dog emerges no less than 202 times in the corpus (156 occurrences in the singular and 46 in the plural), more often than not-as in the examples above-in association with a human figure.

Besides dogs, the animal similes analysed in this article include 10 references to various kinds of horses as well as 10 occurrences of words referring to several types of apes. The former are mentioned as horse or horses 6 times, twice as colt $(s)$, and once as mare and jades (worn-out horses), as in "They fall their crests, and like deceitful jades / Sink in the trial" (Julius Caesar, 4.2.27). Apes are also a significant presence. As noted by Schmidt (1902), Shakespeare put apes and monkeys together "with no discernible difference", and this is why we included in this category the following references: ape $(s)-6$ occurrences, jackan-apes (or jackanapes, i.e. monkey) - 2 occurrences, dog-apes (a type of baboon) -1 , and baboon - 1 . The top of the most referenced animals in likecomparisons is completed by the bull (bull(s) -3 , ox(en) - 2, draught-oxen - 1 , steer $(s)-1$, calf -1 , and cow -1$)$ and various birds of prey (eagle $(s)-4$, owl 2 , haggard -1 , vulture -1 , buzzard -1 ), each counting 9 occurrences. The lion is mentioned 7 times ( 3 occurrences in comedies and 4 in historical plays), whereas the mule and the cock count 5 mentions each. It should be noted that, with the exception of the group formed by birds of prey, all the other animals that emerge more than four times in Shakespeare's direct like-comparisons are 
mammals, and maybe it is not a coincidence that humans belong to the same category as well.

As far as the distribution per type of play is concerned, the frequency of these like-comparisons shows an overall remarkable balance.

\begin{tabular}{|c|c|c|c|c|c|c|}
\hline & \multicolumn{2}{|c|}{ COMEDIES } & \multicolumn{2}{|c|}{$\begin{array}{l}\text { HISTORICAL } \\
\text { PLAYS }\end{array}$} & \multicolumn{2}{|c|}{ TRAGEDIES } \\
\hline & Absolute & $\begin{array}{c}\text { Per } \\
10,000 \\
\text { words }\end{array}$ & Absolute & $\begin{array}{c}\text { Per } \\
10,000 \\
\text { words }\end{array}$ & Absolute & $\begin{array}{c}\text { Per } \\
10,000 \\
\text { words }\end{array}$ \\
\hline $\begin{array}{l}\text { Animal } \\
\text { comparisons } \\
\text { (total) }\end{array}$ & 82 & 2.01 & 55 & 1.97 & 48 & 1.76 \\
\hline Mammals & 41 & 1.01 & 31 & 1.11 & 32 & 1.17 \\
\hline Birds & 18 & 0.44 & 14 & 0.50 & 8 & 0.29 \\
\hline $\begin{array}{l}\text { Reptiles and } \\
\text { amphibians }\end{array}$ & 3 & 0.07 & 1 & 0.04 & 0 & \\
\hline $\begin{array}{l}\text { Fish and water } \\
\text { animals }\end{array}$ & 5 & 0.12 & 4 & 0.14 & 3 & 0.11 \\
\hline Insects and worms & 6 & 0.15 & 5 & 0.18 & 1 & 0.04 \\
\hline Other & 9 & 0.22 & 0 & & 4 & 0.15 \\
\hline \multicolumn{7}{|l|}{$\begin{array}{l}\text { Types of } \\
\text { mammal }\end{array}$} \\
\hline Domestic & 20 & 0.49 & 20 & 0.72 & 16 & 0.59 \\
\hline Wild & 21 & 0.52 & 11 & 0.39 & 16 & 0.59 \\
\hline \multicolumn{7}{|l|}{ Types of bird } \\
\hline Domestic & 7 & 0.17 & 1 & 0.04 & 0 & \\
\hline Wild & 11 & 0.27 & 13 & 0.47 & 6 & 0.22 \\
\hline $\operatorname{bird}(s)$ (as word) & 0 & & 0 & & 2 & 0.07 \\
\hline
\end{tabular}

Table 6: Absolute and relative frequency of animal similes (with like) by type of play

In terms of absolute frequencies, comedies seem to take the lion's share (82 occurrences) as far as animal similes built with like are concerned. However, our corpus includes 17 comedies ( 407,368 words) and only 10 historical plays $\left(\sim 279,210\right.$ words) and 10 tragedies $\left(\sim 273,204\right.$ words $\left.^{1}\right)$. This is why the relative frequencies computed by 10,000 words show a far more accurate picture of the distribution of these comparisons: overall, like-similes referring to animals are

\footnotetext{
${ }^{1}$ The number of words shown here and used in our calculation of relative frequencies per type of play is computed with UAM CorpusTool. According to the parsing algorithm used, the total number of words in these plays may be different with other corpusanalysis tools.
} 
almost equally frequent in the three types of plays at hand, being only slightly underrepresented in tragedies (occurrences per 10,000 thousand words of 2.01, 1.97, and 1.76, respectively). Relative frequencies also show that, for instance, like-comparisons referring to mammals are most frequent in tragedies and historical plays, whereas references to birds appear most often in historical plays, where the category of domestic mammals is also prevalent.

\section{...How Like a Swine He Lies!: The Human and Non-Human in Shakespeare's Animal Similes}

So far, our analysis has focused on just one of the terms involved in Shakespeare's animal similes, showcasing the amazing variety of creatures populating his imaginary universe. However, another goal of this study was to determine how many of these comparisons establish a relationship between a human (as a rule, as the primum comparandum) and an animal element. The results are revealing. According to our annotations, 80\% (148 instances) of the animal similes at hand refer to a human presence:

\begin{tabular}{|l|c|c|c|c|c|c|c|}
\cline { 2 - 7 } \multicolumn{1}{c|}{} & \multicolumn{2}{c|}{ Comedies } & \multicolumn{2}{c|}{$\begin{array}{c}\text { Historical } \\
\text { plays }\end{array}$} & \multicolumn{2}{c|}{ Tragedies } & Overall \\
\cline { 2 - 7 } & Absolute & $\begin{array}{c}\text { Per } \\
10,000 \\
\text { words }\end{array}$ & Absolute & $\begin{array}{c}\text { Per } \\
10,000 \\
\text { words }\end{array}$ & Absolute & $\begin{array}{c}\text { Per } \\
10,000 \\
\text { words }\end{array}$ & Absolute \\
\hline $\begin{array}{l}\text { COMPARISON } \\
\text { WITH } \\
\text { HUMAN } \\
\text { ELEMENT }\end{array}$ & 62 & 1.52 & 46 & 1.65 & 40 & 1.46 & $\mathbf{1 4 8}$ \\
\hline $\begin{array}{l}\text { COMPARISON } \\
\text { WITH NON- } \\
\text { HUMAN } \\
\text { ELEMENT }\end{array}$ & 20 & 0.49 & 9 & 0.32 & 8 & 0.29 & $\mathbf{3 7}$ \\
\hline
\end{tabular}

Table 7: Comparisons with human vs. non-human element

As shown in the table above, the like-comparisons confronting a human and an animal element prevail in the corpus, being slightly more frequent in Shakespeare's historical plays than in the others. In turn, these similes may take various forms, as animals are used to gauge humanity in several of its dimensions. They may be: 
- direct, i.e. comparing a human character —as an individual or a group — with an animal or animal features:

After the moon. If thou art rich, thou'rt poor, For, like an ass, whose back with ingots bows, Thou bear'st thy heavy riches but a journey, And death unloads thee. (Measure for Measure, 3.1.25-28)

- comparing human actions/behaviour with animal behaviour (according to our annotations, these are by far the most common animal similes in the corpus):

Good Helicane that stayed at home,

Not to eat honey like a drone

From others' labours [...] (Pericles, Ch.2.17-19)

or

Some that will evermore peep through their eyes

And laugh like parrots at a bagpiper (Merchant of Venice, 1.1.52-53)

- comparing human appearance to animal appearance:

All furnish'd, all in arms

All plum'd like estridges that wing the wind (Henri IV Part I, 4.1.97-89)

- comparing human feelings to animal (anthropomorphised) feelings, features, or behaviour:

That instant was I turned into a hart, And my desires, like fell and cruel hounds, E'er since pursue me (Twelfth Night, 1.1.21-23)

It should be said that these annotations and comparison types are neither definitive nor clear-cut. They are just meant to provide a clearer overall picture of the two-way referential relationship established between humanity and animality in Shakespeare's similes. Moreover, since the Bard used animals to comment upon and compare all sorts of phenomena, our annotation process has not always been straightforward. For instance, with some like-similes it was difficult to establish whether the primum comparandum was human in nature or not, as in the following example, where the animal analogy is used to comment upon an abstraction:

A blank, my lord. She never told her love,

But let concealment, like a worm i'the bud,

Feed on her damask cheek. (Twelfth Night, 2.4.109-111)

Owing to the abstract nature of the term at hand, i.e. concealment, we decided to include it in the "non-human" category of comparanda, but, needless to say, this choice is not definitive in any way, since one might as well argue that 
abstractions are an essentially human product. However, this kind of argument was beyond the point of our study.

On the other side of our classification of animal similes in Shakespeare's plays, non-human comparanda cover several phenomena too. The analogies to which they belong may be:

- comparing an animal figure to another animal figure:

My hounds are bred out of the Spartan kind;

With ears that sweep away the morning dew;

Crook-kneed, and dewlapped like Thessalian bulls. (A Midsummer Night's Dream, 4.1.118-121)

- comparing a general feeling or action with animal features or behaviour:

[...] Anger is like

A full hot horse, who being allowed his way,

Self-mettle tires him. (Henry VIII, 1.1.132-134)

or

Pray you no more of this, 'tis like the howling

of Irish wolves against the moon. (As You Like It, 5.2.104-105)

- comparing an abstract entity with animal features or behaviour:

And tame the savage spirit of wild war,

That, like a lion fostered up at hand,

It may lie gently at the foot of peace (King John, 5.2.74-76)

- comparing natural phenomena to animal appearance or behaviour:

Have I not heard the sea, puffed up with winds,

Rage like an angry boar chafed with sweat? (The Taming of the Shrew, 1.2.199-200)

As all these examples show, in Shakespeare's plays, animals and their (anthropomorphised) features and behaviours serve as comparanda for a very wide range of both human and non-human entities. But does this two-way relationship established between (non-)humanity and animality have positive or negative undertones? This is the question we tried to tackle when we also attempted to annotate the 185 like-similes identified in the corpus according to the type of connotation they bear. Keeping in mind that this is basically an interpretive process and, therefore, a subjective one, we divided the animal comparisons of interest into three broad categories: (more or less) positive, neutral, and negative similes. In some cases the undertones of the comparison were rather easy to establish, owing to the presence of other elements (e.g. 
negative/positive lexis) in the fragment of interest, whereas in others the decision-making process was less simple.

Similes with a negative connotation focus on animals or animal features which, through human eyes, are seen as dirty, undesirable, harmful, dangerous, unmanageable, etc.

That such a slave as this should wear a sword

Who wears no honesty. Such smiling rogues as these,

Like rats, oft bite the holy cords atwain (King Lear, 2.2.71-72)

Most of the neutral like-comparisons in the corpus contrast animal features or behaviour with human actions without assigning a clearly positive or negative value to them. They are often based on proverbial/cliché views of particular animals or on their usually observed behaviour. For instance, Jaques' famous speech from As You Like It encompasses two neutral animal similes, one referencing the familiar slowness of the snail (an actual characteristic, so neither positively nor negatively connoted), the other the appearance of the leopard/panther, which, for some reason, was anthropomorphically seen as bearded at that time:

Then, the whining schoolboy, with his satchel And shining morning face, creeping like snail Unwillingly to school;

[...] then, a soldier,

Full of strange oaths, and bearded like the pard (2.7.146-151)

It should go without saying that in like-comparisons with positive undertones animal features are seen in a better light. For instance, in the excerpt below, the eagle's majestic nature and its non-human capacity to soar and watch its prey are used to highlight the king's out-of-the-ordinary qualities:

No! Know the gallant monarch is in arms

And like an eagle o'er his aiery towers

To souse annoyance that comes near his nest. (King John, 5.2.148-150)

Overall, the results of this annotation process confirm, at least in part, Shakespeare's fundamental anthropocentrism. Most of the similes of interest depict animals or refer to them in negative terms:

\begin{tabular}{|l|c|c|c|c|c|c|c|}
\cline { 2 - 8 } \multicolumn{1}{c|}{} & \multicolumn{2}{c|}{ Comedies } & \multicolumn{2}{c|}{ Historical plays } & \multicolumn{2}{c|}{ Tragedies } & Overall \\
\cline { 2 - 8 } & Absolute & $\begin{array}{c}\text { Per } \\
10,000 \\
\text { words }\end{array}$ & Absolute & $\begin{array}{c}\text { Per } \\
10,000 \\
\text { words }\end{array}$ & Absolute & $\begin{array}{c}\text { Per } \\
10,000 \\
\text { words }\end{array}$ & Absolute \\
\hline NEGATIVE & 33 & 0.81 & 37 & 1.33 & 27 & 0.99 & $\mathbf{9 7}$ \\
\hline NEUTRAL & 43 & 1.06 & 15 & 0.54 & 13 & 0.48 & $\mathbf{7 1}$ \\
\hline POSITIVE & 6 & 0.15 & 3 & 0.11 & 8 & 0.29 & $\mathbf{1 7}$ \\
\hline
\end{tabular}

Table 8: Comparisons by type of connotation 
As a rule, as shown by the figures in the table above, the human's qualities, or lack thereof, are described and emphasized by analogy or in contrast with negative traits attributed to the animal. The word "animal" itself, however, appears only eight times throughout the entire opus, but this is due to the fact that it was rarely used in the English vernacular before 1590, the more negative terms "beast" and "creature" being far more widespread at the time. (Shannon 79) What the results show is that Shakespeare's rampant anthropocentrism, which was to be expected considering the period in which he wrote, is at times, undercut by his anthropomorphism. Surprisingly enough, when he seeks to describe typically human traits, even what is seen as the best of them, he immediately retorts to animality: swans for love and togetherness: "And wheresoe'er we went, like Juno's swans / Still we went coupled and inseparable" (As You Like It, 1.3.73-74) or robins for romance: "to relish a love-song, like a robin-redbreast" (The Two Gentlemen of Verona, 2.1.19). Even the negative associations, while apparently zoomorphic, are in fact also deeply anthropomorphic since what they essentially describe are not necessarily animal emotions, but typically human ones. Anger, a fundamentally human emotion, is attributed to bees, apes or boars — "Most ignorant of what he's most assur'd / His glassy essence, like an angry ape" (Measure for Measure, 2.2.119-120) while war-like aggression and cruelty are attributed to wolves and hounds: "Will the hateful commons perform for us / Except like curs to tear us all to pieces" (Richard II, 2.2.137-138). Therefore, in Shakespeare's use of animality we may find three attitudinal categories defined by Boehrer as "absolute anthropocentrism," "relative anthropocentrism," and "anthropomorphism" (2002:6). The figures belonging to the last category, however, as Erica Fudge remarks "begin to upset the normal distinction between human and animal." (8384).

When it comes to Shakespeare's most employed figure of animality, the dog, what is particularly interesting is the fact that its negative connotations intersect with issues of both gender and race/ethnicity. Most similes involving dogs refer to male characters who, while negatively portrayed as flatterers or cruel, are also, in contrast to female characters, the active ones. The male/female, active/passive binaries show a superimposition of phallocentrism onto the more visible anthropocentrism. In what concerns race and ethnicity, as Bruce Boehrer also notes, animal figures are frequently associated with "ethnic others". (5). In Titus Andronicus, for instance, Aaron seems to have internalized the Western binary logic when he refers to himself as a "black dog". What our analysis of animal comparisons in Shakespeare ultimately reveals is that, even in the most anthropocentric of times, both non-human and human animality could not be fully repudiated. It rears its head in play after play, from the comedies to the tragedies, like the return of the repressed which cannot be completely banished from the psyche. 


\section{Works Cited}

Anthony, Laurence. AntConc (Version 3.4.3) [Computer Software]. Tokyo: Waseda University, 2014. Available from http://www.laurenceanthony.net/. Web 3 March 2016.

Boehrer, Bruce. Shakespeare among the Animals: Nature and Society in the Drama of Early Modern England, New York: Palgrave, 2002. Print.

Fudge, Erica. "Saying Nothing Concerning the Same: On Dominion, Purity, and Meat in Early Modern England" in Fudge, Erica (ed), Renaissance Beasts: of Animals, Humans, and other wonderful Creatures, Chicago: University of Illinois Press, 2004.70-87. Print.

McEnery, Tony and Andrew Hardie. Corpus Linguistics: Method, Theory and Practice, Cambridge: Cambridge University Press, 2012. Print.

Meyer, Charles F. English Corpus Linguistics. An Introduction, Cambridge: Cambridge University Press, 2004.

O'Keeffe, Anne and Michael McCarthy, eds. The Routledge Handbook of Corpus Linguistics, London: Routledge, 2010. Print.

Schmidt, Alexander. Shakespeare Lexicon and Quotation Dictionary. Berlin: Georg Reimer, 1902. Available online at: http://www.perseus.tufts.edu. Web 3 March 2016.

Shannon, Laurie. The Accommodated Animal: Cosmopolity in Shakespearean Locales, Chicago: University of Chicago Press, 2013. Print. Web 14 September 2015.

Stubbs, Michael. Words and Phrases. Corpus Studies of Lexical Semantics, Oxford: Blackwell Publishing, 2002. Print. 